\title{
Preoperative serum uric acid predicts incident acute kidney injury following cardiac surgery
}

\author{
T. Kaufeld ${ }^{1 *}$, K. A. Foerster ${ }^{2}$, T. Schilling ${ }^{1}$, J. T. Kielstein², J. Kaufeld ${ }^{2}$, M. Shrestha' ${ }^{1}$, H. G. Haller², A. Haverich
} and B. M. W. Schmidt ${ }^{2}$

\begin{abstract}
Background: Acute kidney injury (AKI) following cardiac surgery is a frequent complication and several risk factors increasing its incidence have already been characterized. This study evaluates the influence of preoperative increased serum uric acid (SUA) levels in comparison with other known risk factors on the incidence of AKI following cardiac surgery.

Methods: During a period of 5 month, 247 patients underwent elective coronary artery bypass grafting, valve replacement/ repair or combined bypass and valve surgery. Datas were prospectively analyzed. Primary endpoint was the incidence of AKI as defined by the AKI criteria comparing patients with preoperative serum uric acid (SUA) levels below versus above the median. Multivariate logistic regression analysis was used to identify independent predictors of postoperative AKI.

Results: Thirty (12.1\%) of the 247 patients developed postoperative AKI, 24 of 30 (80\%) had preoperative SUAlevels above the median ( $\geq 373 \mu \mathrm{mol} / \mathrm{I})(\mathrm{OR}: 4.680, \mathrm{Cl} 95 \% 1.840 ; 11.904, p=0.001)$. In the multivariate analysis SUA levels above the median (OR: 5.497, Cl 95\% 1.772; 17.054, $p=0.003$ ), cardiopulmonary bypass (CPB) time $>90 \mathrm{~min}$ (OR: 4.595, Cl 95\% 1.587; 13.305, $p=0.005)$, cardiopulmonary bypass (CPB) $>30$ kg/m² (OR: 3.208, Cl 95\% 1.202; 8 . 562; $p=0.02$ ), and preoperative elevated serum-creatinine levels (OR: 1.015, Cl 95\% 1.001; 1.029, $p=0.04$ ) were independently associated with postoperative AKI.
\end{abstract}

Conclusions: Serum uric acid is an independent risk marker for AKI after cardiac surgery. From all evaluated factors it showed the highest odds ratio.

Keywords: Renal impairment, Cardiac surgery, Serum uric acid, Kidney injury

\section{Background}

Acute kidney injury (AKI) following cardiac surgery is a frequent complication and has a significant impact on postoperative mortality [1-5]: overall mortality after open-heart surgery ranges between 2 and 8\% [5] and raises up to $29 \%$ in patients developing postoperative AKI and even over $60 \%$ in those requiring postoperative renal replacement therapy [4].

Risk factors increasing the incidence of AKI after cardiac surgery imply age $[4,6,7]$, female gender $[1,6-8]$

\footnotetext{
*Correspondence: kaufeld.tim@mh-hannover.de

1 Department of Heart, Thoracic, Transplant and Vascular Surgery, Hannover

Medical School, Carl-Neuberg-Straße 1, 30625 Hannover, Germany

Full list of author information is available at the end of the article
}

and several comorbidities as hypertension [9], peripheral vascular disease $[1,2,4,6]$, diabetes mellitus $[1,2,6,7,9]$, congestive heart failure $[1,2,4]$, chronic obstructive pulmonary disease $[1,2,4]$, prior heart surgery, recent myocardial infarction $(<7-30$ days) $[2,4,6,7,10]$, preoperative creatinine concentrations $>1.3 \mathrm{mg} / \mathrm{dl}$ and current diuretic use $[2,9,11]$. The incidence of AKI is associated with the type of operation: combined surgery (coronary artery bypass grafting plus valvular heart surgery) implies a higher risk for AKI than each procedure by itself $[3,4]$. Valvular heart surgery is described as a single independent risk factor $[1,4,12]$, especially mitral valve replacement or repair [7]. Risk factors concerning the operation itself imply the duration of aortic cross clamp [11],

(c) The Author(s). 2018 Open Access This article is distributed under the terms of the Creative Commons Attribution 4.0 International License (http://creativecommons.org/licenses/by/4.0/), which permits unrestricted use, distribution, and 
need for emergency surgery $[1,6]$, reoperation for bleeding or repeat cardiopulmonary bypass [10], intra-aortic balloon pump (IABP) insertion [6] and number of intraoperative packed red blood cell (PRBC) units transfused [11]. The duration of the on-pump cardiopulmonary bypass $(\mathrm{CPB})$ is viewed as one of the most important predictive marker for the development of postoperative AKI $[1,6,7,13,14]$.

Ejaz et al. [15] have examined the role of serum uric acid (SUA) as a potential risk factor for AKI after cardiac valve and aneurysm surgery. Preoperative SUA higher than an arbitrary level of $6.1 \mathrm{mg} / \mathrm{dl}$ conferred a 4-fold risk for postoperative AKI.

AKI induced by increased uric acid levels commonly occurs in patients with tumor lysis syndrome (TLS). In this context uric acid impairs renal function by intratubular crystal precipitation as well as by inducing oxidative stress and renal inflammation [16]. Kuwabara et al. [17] as well as Feig et al. [18] hypothesized that elevated uric acid levels have a role in kidney disease: they impair endothelial function and cause subtle renal damage.

With regard to Feig et al. [18] and in view of the fact that AKI following cardiac surgery is a frequent complication we performed a study to determine if SUA is an independent predictive marker for AKI in patients undergoing cardiac surgery.

\section{Methods}

In a prospective study we analyzed 247 patients who underwent elective cardiac surgery during a period of 5 months at the Medizinische Hochschule Hannover (MHH), Germany. The procedures were coronary artery bypass grafting (CABG) in 109 patients, valve replacement or repair (VR) in 93 patients, combined heart surgery $(C A B G+V R)$ in 44 patients and resection of left ventricular aneurysm (other) in one patient. Concomitant procedures were the replacement of the aortic root or the aorta ascendens in 27 patients, operation of the carotid artery in 4 patients, insertion of an intra aortic balloon pump (IABP) in 3 patients and the operation of the femoral artery in one patient. The study received a waiver by the Institutional Review Board of the Medizinische Hochschule Hannover (MHH).

Primary endpoint of the study is the incidence of AKI as defined by the AKIN criteria $[19,20]$ comparing patients with preoperative serum uric acid (SUA) levels below versus above the median. Patients with preoperative chronic kidney disease stage 5 (estimated glomerular filtration rate at baseline $<15 \mathrm{ml} / \mathrm{min}$ or on permanent renal replacement therapy), preoperative intensive care unit stay $>24 \mathrm{~h}$ and emergency surgery were not included in this study.

We collected data including demographic variables, type of surgery, comorbidities and preoperative medication.
Preoperative SUA and serum creatinine $(\mathrm{SCr})$ levels were measured in the context of the preoperative routine laboratory assessment. Univariate analysis was performed to determine the association between preoperative SUA levels above the median, demographic parameters, surgery type, renal function, comorbidities, preoperative medication including allopurinol use, intraoperative parameters, and the incidence of AKI. We used $\mathrm{X}^{2}$ - test and two-sided Fisher's exact test as appropriated. $P$-value $<0.05$ was considered statistically significant.

Binary logistic regression analysis was performed to evaluate if SUA levels above the median are an independent marker for developing AKI following cardiac surgery and to determine further independent risk factors. The following variables showed a $p$-value $<0.2$ in univariate analysis and entered into the logistic regression analysis: preoperative SUA > median, body mass index $(\mathrm{BMI})>30 \mathrm{~kg} / \mathrm{m}^{2}$, valve replacement or repair (VR), coronary artery bypass grafting (CABG), preoperative serum creatinine $(\mathrm{SCr})>$ median, diabetes, preoperative diuretic use and cardiopulmonary bypass (CPB) time $>90 \mathrm{~min}$. Referring to previous studies we chose $\mathrm{CPB}$ - time $>90 \mathrm{~min}$ as the strongest representative factor for operations' severity $[1,6,7,13,14]$. Therefore operation- time, aortic cross clamp (ACC) time, need for reoperation and numbers of intraoperative transfused FFP did not enter into logistic regression analysis. $P$-value $<0.05$ was considered statistically significant.

Statistical analysis was performed using SPSS, Version 19, IBM Germany, Ehningen.

\section{Results}

Demographic data are shown in Table 1. Preoperative SUA levels above the median $(\geq 373 \mu \mathrm{mol} / \mathrm{l})$ were significantly associated with higher serum creatinine and GFR, more diuretic and less allopurinol use.

Thirty (12.1\%) of 247 patients developed AKI following cardiac surgery. $24(80 \%)$ of 30 patients that developed postoperative AKI had preoperative SUA levels above the median (OR: 4.680, CI 95\% 1.840; 11.904, $p=$ 0.001 , Table 2). 8 (3.2\%) of 247 patients required postoperative renal replacement therapy, 7 (87.5\%) of 8 patients had SUA levels above the median (OR: 7.299, CI 95\% $0.884 ; 60.240, p=0.066)$. There was no intrahospital mortality.

In univariate analysis a BMI $>30 \mathrm{~kg} / \mathrm{m}^{2}$ (OR: 3.220 , CI $95 \%$ 1.472; 7.045, $p=0.004$ ) and CABG (OR: 0.418 , CI $95 \% 0.178 ; 0.979, p=0.049$ ), preoperative serum creatinine (OR: 4.509, CI 95\% 1.967; 10.338, $p$ $<0.001$ ), chronic kidney disease (OR: 3.938, CI 95\% $1.763 ; 8.800, p=0.001$ ) and diabetes (OR: 2.609, CI $95 \% 1.195 ; 5.695, p=0.017)$ were significantly associated with the incidence of AKI. Intraoperative parameters as operation time $>300$ min (OR: 4.466, CI 95\% 
Table 1 Baseline patient characteristics

\begin{tabular}{|c|c|c|c|}
\hline Variables & Uric acid > median $(n=124)$ & Uric acid $<$ median $(n=123)$ & $P$-Value \\
\hline Serum uric acid $(\mu \mathrm{mol} / /$; mean $\pm S D)$ & $464.94 \pm 91.066$ & $301.93 \pm 45.434$ & \\
\hline \multicolumn{4}{|l|}{ Demographics } \\
\hline Age (yr; mean \pm SD) & $67.40 \pm 12.221$ & $68.26 \pm 10.851$ & 0.557 \\
\hline Female gender $(n ; \%)$ & $34(27.4)$ & $48(39.0)$ & 0.053 \\
\hline $\mathrm{BMI}($ mean $\pm \mathrm{SD})$ & $28.213 \pm 4.4752$ & $27.089 \pm 4.5357$ & 0.054 \\
\hline \multicolumn{4}{|l|}{ Surgery type: $n(\%)$} \\
\hline Valves & $43(34.7)$ & $50(40.7)$ & 0.335 \\
\hline Bypass & $59(47.6)$ & $50(40.7)$ & 0.275 \\
\hline Valves + Bypass & $22(17.7)$ & $22(17.9)$ & 0.976 \\
\hline Other & - & $1(0.8)$ & \\
\hline \multicolumn{4}{|l|}{ Renal function } \\
\hline Serum- Creatinine $(\mu \mathrm{mol} / /$; mean $\pm \mathrm{SD})$ & $101.35 \pm 31.794$ & $81.89 \pm 26.336$ & $<0.001$ \\
\hline CKD- Epi- GFR (mean \pm SD) & $66.865 \pm 22.0789$ & $78.676 \pm 18.1805$ & $<0.001$ \\
\hline \multicolumn{4}{|l|}{ Comorbidities: $n$ (\%) } \\
\hline Hypertension & $114(91.9)$ & $110(89.4)$ & 0.264 \\
\hline CKD & 38 (30.6) & $17(13.8)$ & 0.001 \\
\hline Diabetes & $41(33.1)$ & $27(21.0)$ & 0.050 \\
\hline PVD & $17(13.7)$ & $13(10.6)$ & 0.452 \\
\hline Congestive heart failure & $94(75.8)$ & $89(72.4)$ & 0.332 \\
\hline COPD & $19(15.3)$ & $13(10.6)$ & 0.257 \\
\hline Previous heart surgery & $16(12.9)$ & $9(7.3)$ & 0.130 \\
\hline \multicolumn{4}{|l|}{ Medication: $n(\%)$} \\
\hline ACE- Inhibitor & $67(54.0)$ & $62(50.4)$ & 0.250 \\
\hline AT1- Receptor- Blocker & $16(12.9)$ & $17(13.8)$ & 0.984 \\
\hline Calcium Antagonist & $27(21.8)$ & $28(22.8)$ & 0.940 \\
\hline Beta- Blocker & $76(61.3)$ & $73(59.3)$ & 0.371 \\
\hline Diuretic & $56(45.2)$ & $43(35.0)$ & 0.034 \\
\hline Lipid- lowering drugs & $51(41.1)$ & $54(43.9)$ & 0.983 \\
\hline Allopurinol & $3(2.4)$ & $12(9.8)$ & 0.020 \\
\hline \multicolumn{4}{|l|}{ Intraoperative parameters } \\
\hline Operation time (minutes; mean \pm SD) & $213.26 \pm 85.004$ & $203.81 \pm 81.271$ & 0.373 \\
\hline CPB- time (minutes; mean \pm SD) & $104.08 \pm 67.311$ & $103.31 \pm 64.880$ & 0.928 \\
\hline ACC- time (minutes; mean \pm SD) & $60.53 \pm 40.365$ & $61.31 \pm 36.619$ & 0.876 \\
\hline PRBC (mean \pm SD) & $2.30 \pm 3.193$ & $1.98 \pm 2.054$ & 0.343 \\
\hline $\mathrm{FFP}($ mean $\pm \mathrm{SD})$ & $1.44 \pm 2.470$ & $0.96 \pm 1.822$ & 0.084 \\
\hline Need for reoperation $(n ; \%)$ & $17(13.7)$ & $16(13.0)$ & 0.872 \\
\hline
\end{tabular}

BMI Body mass index, CKD- Epi- GFR Chronic Kidney Disease Epidemiology Collaboration Glomerular Filtration Rate, CKD Chronic Kidney Disease, PVD Peripheral Vascular Disease, COPD Chronic Obstructive Pulmonary Disease, ACE Angiotensin- converting Enzyme, AT1- Receptor- Blocker Angiotensin- 1- Receptor- Blocker, CPB Cardiopulmonary Bypass, ACC Aortic Cross Clamp, PRBC Packed Red Blood Cells, FFP Fresh Frozen Plasma

$1.795 ; 11.115, \quad p=0.002)$, cardiopulmonary bypass (CPB) time $>90$ min (OR: 4.360, CI 95\% 1.854; 10.252, $\mathrm{p}=0.001$ ), aortic cross clamp (ACC) time above the median (OR: 2.502, CI 95\% 1.124; 5.572, $p$ $=0.036)$ and the number of intraoperative transfused fresh frozen plasma (FFP) (OR: 2.776, CI 95\% 1.279;
6.024, $p=0.012)$ go along with a higher risk for postoperative AKI.

After adjusting for BMI, CABG, VR, CPB > $90 \mathrm{~min}$, preoperative $\mathrm{SCr}$, diabetes and preoperative diuretic use the following variables were independently associated with AKI: SUA levels above the median (OR: 5.497, CI 
Table 2 Univariate analysis of predictors of AKI

\begin{tabular}{|c|c|c|}
\hline Variables & Odds ratio (Cl 95\%) & $P$-value \\
\hline Serum uric acid $>$ median & $4680(1.840 ; 11.904)$ & 0.001 \\
\hline \multicolumn{3}{|l|}{ Demographics } \\
\hline Age $>60 \mathrm{yr}$ & $1.7490 .581 ; 5.263$ & 0.467 \\
\hline Male gender & $0.840(0.379 ; 1.860)$ & 0.682 \\
\hline $\mathrm{BMI}>30 \mathrm{~kg} / \mathrm{m}^{2}$ & $3.220(1.472 ; 7.045)$ & 0.004 \\
\hline \multicolumn{3}{|l|}{ Surgery type: n (\%) } \\
\hline Valves & $1.782(0.827 ; 3.839)$ & 0.161 \\
\hline Bypass & $0.418(0.178 ; 0.979)$ & 0.049 \\
\hline Valves + Bypass & $1.481(0.592 ; 3.704)$ & 0.444 \\
\hline \multicolumn{3}{|l|}{ Renal function } \\
\hline Serum- Creatinine $>$ median & $4.509(1.967 ; 10.338)$ & $<0.001$ \\
\hline CKD- Epi- GFR $<60 \mathrm{ml} / \mathrm{min}$ & $2.875(1.321 ; 6.257)$ & 0.009 \\
\hline \multicolumn{3}{|l|}{ Comorbidities: n (\%) } \\
\hline Hypertension & $1.357(0.300 ; 6.143)$ & 1.000 \\
\hline CKD & $3.938(1.763 ; 8.800)$ & 0.001 \\
\hline Diabetes & $2.609(1.195 ; 5.695)$ & 0.017 \\
\hline PVD & $1.990(0.739 ; 5.355)$ & 0.228 \\
\hline Congestive heart failure & $1.553(0.563 ; 4.284)$ & 0.488 \\
\hline COPD & $1.896(0.706 ; 5.091)$ & 0.237 \\
\hline Previous heart surgery & $3.280(1.238 ; 8.689)$ & 0.021 \\
\hline \multicolumn{3}{|l|}{ Medication: n (\%) } \\
\hline ACE- Inhibitor & $1.131(0.503 ; 2.544)$ & 0.839 \\
\hline AT1- Receptor- Blocker & $1.289(0.452 ; 3.671)$ & 0.579 \\
\hline Calcium Antagonist & $2.206(0.962 ; 5.056)$ & 0.064 \\
\hline Beta- Blocker & $1.260(0.526 ; 3.014)$ & 0.672 \\
\hline Diuretic & $1.783(0.801 ; 3.971)$ & 0.161 \\
\hline Lipid- lowering drugs & $0.688(0.307 ; 1.546)$ & 0.421 \\
\hline Allopurinol & $0.476(0.060 ; 3.769)$ & 0.700 \\
\hline \multicolumn{3}{|l|}{ Intraoperative parameters } \\
\hline Operation time $>300 \mathrm{~min}$ & $4.466(1.795 ; 11.115)$ & 0.002 \\
\hline CPB- time $>90 \mathrm{~min}$ & $4.360(1.854 ; 10.252)$ & 0.001 \\
\hline ACC- time $>$ median & $2.502(1.124 ; 5.572)$ & 0.036 \\
\hline PRBC transfusion & $0.710(0.327 ; 1.540)$ & 0.420 \\
\hline FFP transfusion & $2.776(1.279 ; 6.024)$ & 0.012 \\
\hline Need for reoperation & $5.132(2.164 ; 12.170)$ & $<0.001$ \\
\hline
\end{tabular}

BMI Body mass index, CKD- Epi- GFR Chronic Kidney Disease Epidemiology Collaboration Glomerular Filtration Rate, CKD Chronic Kidney Disease, PVD Peripheral Vascular Disease, COPD Chronic Obstructive Pulmonary Disease, ACE Angiotensin- converting Enzyme; AT1- Receptor-Blocker Angiotensin- 1Receptor- Blocker, CPB Cardiopulmonary Bypass, ACC Aortic Cross Clamp, PRBC Packed Red Blood Cells, FFP Fresh Frozen Plasma

95\% 1.772; 17.054, $p=0.003)$, BMI > $30 \mathrm{~kg} / \mathrm{m}^{2}$ (OR: 3.208 , CI 95\% 1.202; 8.562; $p=0.02$ ), CPB time $>90 \mathrm{~min}$ (OR: 4.595 , CI $95 \% 1.587 ; 13.305, p=0.005)$ and preoperative elevated SCr levels (OR: 1.015, CI 95\% 1.001; $1.029, p=0.04)$. In contrast, type of surgery (CABG, VR), diabetes and preoperative diuretic drug use were not independently associated with the incidence of AKI following cardiac surgery in logistic regression analysis. The results of binary logistic regression analysis are presented in Table 3.

\section{Discussion}

This study evaluates the influence of preoperative increased serum uric acid (SUA) levels and further concomitant factors on the incidence of AKI following cardiac surgery. We detected SUA as an independent and strong predictive marker for developing AKI after VR, CABG and VR plus CABG. BMI $>30 \mathrm{~kg} / \mathrm{m}^{2}$, preoperative elevated serum creatinine ( $\mathrm{SCr}$ ) levels and CPB duration $>90 \mathrm{~min}$ are as well independently associated with a higher incidence of postoperative AKI.

The acute tubular necrosis (ATN) as the histopathological correlate of postoperative AKI results from reduced renal perfusion by intraoperative impaired hemodynamics and low cardiac output $[1,4,21]$. A longer duration of $\mathrm{CPB}$ goes along with higher risk for renal ischemia and causes renal inflammation by inducing an increase in cytokines such as TNF- $\alpha$, IL-1 and IL-6. Moreover $\mathrm{CPB}$ can cause episodic microembolism leading to renal infarction. $[1,4,14]$.

In patients with tumor lysis syndrome (TLS) increased uric acid induces AKI by intratubular crystal precipitation as well as on a crystal- independent pathway [16]. By stimulating the renin- angiotensin system, reducing nitric oxide (NO) release from endothelial cells and inhibiting NO synthase 1 uric acid causes renal vasoconstriction and leads to renal ischemia and hypertension [22]. Uric acid is also considered to have proinflammatory properties: in-vitro it induced the expression of C-reactive protein (CRP) by human endothelial and vascular smooth muscle cells and the production of the

Table 3 Multivariable analysis of predictors of AKI

\begin{tabular}{lll}
\hline Variables & Odds ratio $($ Cl 95\%) & $P$-Value \\
\hline Serum uric acid > median & $7131(2.061 ; 24.667)$ & 0.002 \\
$\mathrm{BMI}>30 \mathrm{~kg} / \mathrm{m}^{2}$ & $3.158(1.102 ; 8.468)$ & 0.020 \\
Valves & $0.363(0.094 ; 1.399)$ & 0.141 \\
Bypass & $1.016(0.236 ; 4.387)$ & 0.983 \\
Diabetes & $0.452(0.147 ; 1.389)$ & 0.166 \\
Diuretic & $0.988(0.356 ; 2.118)$ & 0.769 \\
Calcium Antagonist & $1.864(0.628 ; 5.537)$ & 0.262 \\
CPB- time $>90$ min & $4.337(1.478 ; 12.304)$ & 0.018 \\
Serum Creatinine & $0.984(0.969 ; 0.999)$ & 0.032 \\
FFP Transfusion & $1.007(0.795 ; 1.277)$ & 0.952 \\
Need for Reoperation & $7.154(1.917 ; 26.699)$ & 0.003 \\
Previous Heart Surgery & $2.205(0.581 ; 8.375)$ & 0.245 \\
\hline
\end{tabular}

$B M I$ Body mass index, CPB Cardiopulmonary bypass 
monocyte chemoattractant protein-1 (MCP-1) [23, 24]. By stimulating the proliferation of vascular smooth muscle cells while inhibiting endothelial cell growth at the same time, uric acid impairs renal autoregulation and reduces the GFR [22, 25]. Those mechanisms result in glomerulosclerosis, interstitial fibrosis and arteriolar disease [18].

So far clinical and experimental studies have demonstrated that increased SUA can cause AKI and can induce progression of chronic kidney disease in a non- operative setting [26-28]. Ejaz et al. [15] offered preliminary indication that uric acid impacts the development of AKI following cardiac surgery. By regarding a small study population of 58 patients increased preoperative SUA levels above an arbitrary level of $6.1 \mathrm{mg} / \mathrm{dl}$ determined a 4-fold risk for AKI. Common procedures as CABG and CABG plus VR were not examined in this study. Talwar et al. [29] found that preoperative allopurinol treatment in patients undergoing valvular heart surgery is associated with decreased postoperative inotropic requirement and duration of postoperative mechanical ventilation and shorter hospital stay.

According to several studies we could verify $\mathrm{CPB}$ time as an independent intraoperative risk factor for AKI following cardiac surgery $[1,6,7,13,14]$. Chertow et al. [2] have already detected preoperative increased $\mathrm{SCr}$ as an important marker for postoperative AKI. Although the incidence of AKI after cardiac surgery is described as more frequent in valvular heart surgery or in CABG plus VR $[1,3,4,12]$, we could not verify the association of postoperative AKI with the type of surgery.

\section{Conclusion}

In conclusion, we assume that hyperuricemia could lead to AKI by two different pathways: chronically it may have induced subtle renal damage that predisposes to AKI and that may not be preoperatively detected by serum creatinine. Acutely the effect of intraoperative renal hypoperfusion may be aggravated by the proinflammatory and prooxidative properties of SUA.

Finally, our data indicates that measuring of SUA levels may contribute to preoperative risk assessment. Inhibition of xanthin oxidase should be evaluated in prospective randomised controlled trials.

\footnotetext{
Abbreviations

ACC: Aortic cross clamp; AKI : Acute kidney injury; ATN: Acute tubular necrosis; ATN: Acute tubular necrosis; CPB: Cardiopulmonary bypass; FFP: Fresh frozen plasma; IABP: Intra-aortic balloon pump; MCP-1: Monocyte chemoattractant protein-1; MHH: Medizinische Hochschule Hannover; NO: Nitric oxide; OR: Odds ratio; PRBC: Packed red blood cell; SCr: Serum creatinine; SUA: Serum uric acid; TLS: Tumor lysis syndrome; VR: Valve replacement/repair
}

\section{Acknowledgements}

Parts of the results of this study were presented at the 49th ERA-EDTA CONGRESS, PARIS, France and were published as an Abstract in AKI - Clinical
Nephrology Dialysis Transplantation, Volume 27, Issue suppl_2, 1 May 2012, Pages ii348-ii377.

\section{Availability of data and materials}

The datasets used and/or analysed during the current study are available from the corresponding author on reasonable request.

\section{Authors' contributions}

TK has processed the experimental data, performed the analysis, and drafted the manuscript. KAF has processed the experimental data, performed the analysis, and drafted the manuscript. BMWS took part in the development of the conception and design and has been involved in drafting the manuscript and revising it critically for important content. He has given final approval of the version and agreed to be accountable for all aspects of the work. TS took part in the development of the conception and design and has been involved in drafting the manuscript and revising it critically for important content. He has given final approval of the version and agreed to be accountable for all aspects of the work. JTK took part in the development of the conception and design and has been involved in drafting the manuscript and revising it critically for important content. He has given final approval of the version. He agreed to be accountable for all aspects of the work. JK took part in the development of the conception and design and has been involved in drafting the manuscript and revising it critically language aspects and other important content. She has given final approval of the version and agreed to be accountable for all aspects of the work. MS took part in the development of the conception and the design of this study especially from surgeon view. He has given final approval of the version and agreed to be accountable for all aspects of the work.All authors have read and approved the manuscript. $\mathrm{HGH}$ took part in the development of the conception and design and has been involved in drafting the manuscript and revising it critically for important content. He has given final approval of the version and agreed to be accountable for all aspects of the work. AH took part in the development of the conception and design from heart surgeons view and has been involved in drafting the manuscript and revising it critically for important content. He has given final approval of the version and agreed to be accountable for all aspects of the work. All authors read and approved the final manuscript.

\section{Ethics approval and consent to participate}

The study received a waiver by the Institutional Review Board of the Medizinische Hochschule Hannover $(\mathrm{MHH})$. All data were collected during the daily routine. No additional blood samples were collected and no further examinations performed.

\section{Consent for publication}

"Not applicable"; Datas were collected in the context of the pre-and postoperative routine laboratory assessment.

\section{Competing interests}

All authors have no competing interests in connection with the submitted article. Furthermore all authors have no relationship with industry and financial associations in this study.

\section{Publisher's Note}

Springer Nature remains neutral with regard to jurisdictional claims in published maps and institutional affiliations.

\section{Author details}

${ }^{1}$ Department of Heart, Thoracic, Transplant and Vascular Surgery, Hannover Medical School, Carl-Neuberg-Straße 1, 30625 Hannover, Germany. ${ }^{2}$ Department of Nephrology and Hypertension, Hannover Medical School, Carl-Neuberg-Str.1, Hannover 30625, Germany.

Received: 12 January 2018 Accepted: 26 June 2018

Published online: 04 July 2018

\section{References}

1. Rosner MH, Okusa MD. Acute kidney injury associated with cardiac surgery. Clin J Am Soc Nephrol. 2006;1:19-32. 
2. Chertow GM, Lazarus JM, Christiansen CL, Cook EF, Hammermeister KE, Grover F, Daley J. Preoperative renal risk stratification. Circulation. 1997;95: 878-84

3. Martinelli SM, Patel UD, Phillips-Bute BG, Milano CA, Archer LE, StaffordSmith M, Shaw AD, Swaminathan M. Trends in cardiac surgery- associated acute renal failure in the United States: disproportionate increase after heart transplantation. Ren Fail. 2009;31:633-40.

4. Rodrigues AJ, Evora PRB, Bassetto S, Alves Júnior L, Scorzoni Filho A, Araújo WF, Vicente WA. Risk factors for acute renal failure after heart surgery. Ren Bras Cir Cardiovasc. 2009;24(4):441-6.

5. Thakar CV, Arrigain S, Worley S, Yared J-P, Paganini EP. A clinical score to predict acute renal failure after cardiac surgery. J Am Soc Nephrol. 2005;16:162-8.

6. Ahmadi H, Karimi A, Davoodi S, Movahedi N, Marzban M, Abbasi K, Omran SA, Shirzad M, Abbasi SH, Tazik M. Determinant factors of renal failure after coronary artery bypass grafting with on-pump technique. Med Princ Pract. 2009;18(4):300-4.

7. Bove T, Calabrò MG, Landoni G, Aletti G, Marino G, Crescenzi G, Rosica C, Zangrillo $\mathrm{A}$. The incidence and risk of acute renal failure after cardiac surgery. J Cardiothorac Vasc Anesth. 2004;18(4):442-5.

8. Thakar CV, Liangos O, Yared JP, Nelson D, Piedmonte MR, Hariachar S, Paganini EP. ARF after open- heart surgery: influence of gender and race. Am J Kidney Dis. 2003;41(4):742-51.

9. Metz LI, LeBeau ME, Zlabek JA, Mathiason MA. Acute renal failure in patients undergoing cardiothoracic surgery in a community hospital. WMJ. 2009; 108(2):109-14

10. Chertow GM, Levy EM, Hammermeister KE, Grover F, Daley J. Independent association between acute renal failure and mortality following cardiac surgery. Am J Med. 1998;104(4):343-8.

11. Perez-Valdivieso JR, Monedero P, Vives M, Garcia-Fernandez N. Bes-Rastrollo M for the GEDRCC (Grupo Español de Disfunción renal en Cirugía Cardiaca): cardiac-surgery associated acute kidney injury requiring renal replacement therapy. A Spanish retrospective case-cohort study. BMC Nephrol. 2009;10: 27.

12. Grayson $A D$, Khater $M$, Jackson $M$, Fox MA. Valvular heart operation is an independent risk factor for acute renal failure. Ann Thorac Surg. 2003;75(6): 1829-35.

13. Boldt J, Brenner T, Lehmann A, Suttner SW, Kumle B, Isgro F. Is kidney function altered by the duration of cardiopulmonary bypass? Ann Thorac Surg. 2003;75(3):906-12.

14. Taniguchi FP, De Souza AR, Martins AS. Cardiopulmonary bypass time as a risk factor for acute renal failure. Braz J Cardiovasc Surg. 2007;22(2):201-5.

15. Ejaz AA, Beaver TM, Shimada M, Sood P, Lingegowda V, Schold JD, Kim T, Johnson RJ. Uric acid: a novel risk factor for acute kidney injury in high-risk cardiac surgery patients. Am J Nephrol. 2009;30(5):425-9.

16. Shimada M, Johnson RJ, May WS Jr, Lingegowda V, Sood P, Nakagawa T, Van QC, Dass B, Ejaz AA. A novel role for uric acid in acute kidney injury associated with tumor lysis syndrome. Nephrol Dial Transplant. 2009;24: 2960-4.

17. Kuwabara M, Bjornstad P, Hisatome I, Niwa K, Roncal-Jimenez CA, AndresHernando A, Jensen T, Milagres T, Sato Y, Garcia G, Ohno M, Lanaspa MA, Johnson RJ. Elevated serum uric acid level predicts rapid decline in kidney function. Am J Nephrol. 2017:45(4):330-7. Epub 2017 Mar 11

18. Feig DI, Kang D-H, Johnson RJ. Uric acid and cardiovascular risk. N Engl J Med. 2008;359(17):1811-21.

19. Bellomo R, Ronco C, Kellum JA, Mehta RL, Palevsky P. The ADQI workgroup: acute renal failure - definition, outcome measures, animal models, fluid therapy and information technology needs: the second international consensus conference of the acute Dialysis quality initiative (ADQI) group. Crit Care. 2004;8:204-12.

20. Mehta RL, Kellum JA, Shah SV, Molitoris BA, Ronco C, Warnock DG, Levin A. The acute kidney injury network. Acute kidney injury network: report of an initiative to improve outcomes in acute kidney injury. Crit Care. 2007;11:31.

21. Bahar I, Akgul A, Ozatik MA, Vural KM, Demirbag AE, Boran M, Tasdemir O. Acute renal failure following open heart surgery: risk factors and prognosis. Perfusion. 2005;20:317-22.

22. Ejaz AA, Mu W, Kang D-H, Roncal C, Sautin YY, Henderson G, Tabah-Fisch I, Keller B, Beaver TM, Nakagawa T, Johnson RJ. Could uric acid have a role in acute renal failure? Clin J Am Soc Nephrol. 2007;2:16-21.

23. Kang D-H, Park SK, Lee IK, Johnson RJ. Uric acid-induced C-reactive protein (CRP) expression: implication on cell proliferation and nitric oxide production of human vascular cells. J Am Soc Nephrol. 2005;16:3553-62.
24. Kannelis J, Watanabe S, Li JH, Kang D-H, Li P, Nakagawa T, Wamsley A, Sheikh-Hamad D, Lan HY, Feng L, Johnson RJ. Uric acid stimulates monocyte chemoattractant Protein-1 production in vascular smooth muscle cells via mitogen-activated protein kinase and Cyclooxygenase-2. Hypertension. 2003;41(6):1287-93.

25. Sánchez- Lozada LG, Tapia E, Santamaría J, Avila- Casado C, Soto V, Nepomuceno T, Rodríguez-Iturbe B, Johnson RJ, Herrera-Acosta J. Mild hyperuricemia induces vasoconstriction and maintains glomerular hypertension in normal and remnant kidney rats. Kidney Int. 2005;67:237-47.

26. Obermayr RP, Temml C, Gutjahr G, Knechtelsdorfer M, Oberbauer R, KlauserBraun R. Elevated uric acid increases the risk for kidney disease. J Am Soc Nephrol. 2008;19:2407-13.

27. Yamada T, Fukatsu M, Suzuki S, Wada T, Joh T. Elevated serum uric acid predicts chronic kidney disease. Am J Med Sci. 2011:342(6):461-6.

28. Hsu C-J, Iribarren C, McCulloch CE, Darbinian J, Go AS. Risk factors for endstage renal disease. Arch Intern Med. 2009;169(4):342-50.

29. Talwar S, Sandeep JA, Choudhary SK, Velayoudham D, Lakshmy R, Kasthuri $J M$, Kumar AS. Effect of preoperative administration of allopurinol in patients undergoing surgery for valvular heart diseases. Eur $J$ of Cardiothorac Surg. 2010;38:86-90.

\section{Ready to submit your research? Choose BMC and benefit from:}

- fast, convenient online submission

- thorough peer review by experienced researchers in your field

- rapid publication on acceptance

- support for research data, including large and complex data types

- gold Open Access which fosters wider collaboration and increased citations

- maximum visibility for your research: over $100 \mathrm{M}$ website views per year

At BMC, research is always in progress.

Learn more biomedcentral.com/submissions 